\title{
Ramayana Myth Retold in Hubbu and Kitab Omong Kosong
}

\author{
Tjahjono Widijanto, Herman J. Waluyo ${ }^{2}$, Suyitno3 ${ }^{3}$, Suminto A. Sayuti ${ }^{4}$ \\ ${ }^{1}$ Student of Doctorate Program of Universitas Sebelas Maret, Postgraduate Program of \\ University of Sebelas Maret Surakarta, Indonesia.Email: tjahwid@yahoo.co.id \\ ${ }^{2,3}$ Faculty of Teacher Training and Education, University of Sebelas Maret, Surakarta, \\ Indonesia \\ 4Faculty of Language and Art, State University of Yogyakarta, Yogyakarta, Indonesia
}

\begin{abstract}
The study focused on the myth of Ramayana in Kitab Omong Kosong and Hubbu. It adopted a qualitative approach and descriptive-interpretative data analysis technique by referring to the Analysis of Cultural Studies through multi-disciplinary theories of poststructuralism concerning the nature of difference and multicultural as well as the rejection to metanarrative. The poststructuralism theory which is introduced in this study is the deconstruction theory that has three characteristics. Firstly, deconstruction will offer a strategy to identify contradictions in the political thoughts or ideological tendencies that consciously and unconsciously arise in the texts. Secondly, through deconstruction, the literary texts and their contexts and traditions can be treated as a means to open up new possibilities of assumptions and changes that for long have been deemed impossible. Thirdly, deconstruction facilitates the decomposition of strict ideologies in language and mind. The findings revealed that Kitab Omong Kosong adopted Ramayana's last episode, Uttara Kanda in dismantling the prevailing myths. The dismantlement occurred to the myths of satriya (knights), war and the king's power, as well as the deconstruction of binary opposition in the narrative. Meanwhile, Hubbu adopted Ramayana's first episode, Bala Kanda. It showed the cultural dialects between Javanese culture and pesantren (Islamic school) life in the form of syncretism of wayang (puppet) myth and pesantren (Islamic school) culture. In addition to the cultural syncretism, the novel also offered dialogical texts by syncretizing other narrative elements, such as oral literary genre, wayang genre, and babad genre in the forms of modern narrative.
\end{abstract}

Keywords: myth, Ramayana, novel.

\section{Introduction}

A literary work is perceived as an intersubjective system of a cultural symbol in society. As an intersubjective cultural symbol, it is neither an artifact nor material fact, however rather as a mental fact, fact of collective cultural awareness, or social fact regarding the people that have produced it. The concept implies that a literary work is inseparable from the cultural dialectical context and process.

Literary works especially novels can present the myth of confirmation (myth of concern) and the myth of dismantlement/liberation (myth of freedom). Regarding the myth of concern, literary works produce texts that reinforce or confirm the prevailing myths in society. Meanwhile,

(C) AesthetixMS 2020. This Open Access article is published under a Creative Commons Attribution Non-Commercial 4.0 International License (http://creativecommons.org/licenses/by-nc/4.0/), which permits non-commercial re-use, distribution, and reproduction in any medium, provided the original work is properly cited. For citation use the DOI. For commercial re-use, please contact editor@rupkatha.com. 
regarding the myth of freedom, literary works attempt to change, modify, revolt, or deconstruct a certain myth (Yunus, 1981: 63).

The Indonesian literature even receives foreign influences throughout its development, including the Western and Eastern influences. In the early $2 \mathrm{O}^{\text {th }}$ century, the Western literary genre was not the only cultural product that expanded to the country, however, the ideas and spirit of individuality did too. M. Yamin passionately wrote his sonnets and Rustam Efendi also attempted to introduce his poems as the representation of his brave experiment in producing Indonesian poetries by ignoring Malay literary tradition. However, a number of Indonesian writers did not enthusiastically welcome the Western influences, including Sanusi Pane whose poetic patterns remained with rhyme variations captured with modernity and Amir Hamzah whose poems successfully had combined Western individualism with traditional Malay poetries. In the field of prose, Marah Rusli's romance did not necessarily welcome all of the narrative rules of Western novels, however, still bond to the traditional narrative rules of ethnicity, namely the kaba tradition.

Such a process was increasingly adopted by the latest Indonesian literary authors, including Indonesian writers from Java. The Javanese writers commonly lived in the suburbs and were in an attempt to incorporate the Javanese ethnic cultures into the national culture. It emerged as a heavy and complicated process, as at the certain point, they undeniably longed for their past cultural memories when they had to reorganize the existence and position of their "old hometown" as well as their Javanese culture and literature. However, at the same time, they were urged to develop, support, and strengthen the position and function of Indonesian literary cultures as their new hometown. The old hometown increasingly turned as a mere collective memory since the establishment of a new hometown became an inevitable necessity for them. In this process, several Javanese writers experienced emotional problems, such as confusion, doubt, and even paradox. Goenawan Mohammad, Linus Suryadi AG, and Darmanto Yatman admitted such a condition several years ago.

Until now, in the process of "new homeland" establishment throughout all of the situations and emotions, the current Indonesian literary texts continue to manage, reconstruct, even dismantle the old materials and old myths to produce new paradigms and thoughts. Among those literary works, Kitab Omong Kosong (2013) written by Seno Gumira Ajidarma and Hubbu (2007) written by Mashuri were investigated through this study. Both of these novels departed from the Ramayana myth and feature new interpretations and treatment to the wayang (puppet) myth.

\section{Literature Review}

\section{Wayang As Part of Javanese Myth}

Myth is a phenomenon that evolves in human life. It is similar to a formal or informal institution, in terms of individual and social matters. The myth appears as the product of traditional and modern society. In traditional society, the myth exists as a personification of nature or animals. Meanwhile, in modern society, it is a personification of all the surrounding objects and the manifestation of assumptions, paradigms, and visions of current wishes.

In traditional society, a myth is more stagnant and slower in receiving a shift, especially through the use of oral literature as its dissemination pathway. Therefore, traditional myths reach such absolute stability in the fact and fiction which can no longer be decomposed and transformed into a coherent whole. 
Wayang (puppet) is one of the renowned old myths that play an important role in Javanese society, as it becomes an aesthetic inspiration and exploration for modern Indonesian authors. The Javanese wayang myth is explicitly narrated in Serat Centhini vol. IX poem 598 Megatruh song verse 3 and 4: //Janma tama karya lajem mring pandulu/ asmitaning Hyang Sejati, dalang lan wayang dinunung/ pamonggone Hyang mawarni/ karya upameng pandulon"//, //"Kelir jagad gumelar wayang pinanggung/ asnapun mahluking Widhi/gedebog bantala wegung/ blencong padhanging urip/ gamelan gendinging lakon"/. In this part, wayang (puppet) functions to provide the reflection of humans in the world that evolves through a process in a limited period based on the law of cause and effect, which in Javanese concept is called cakra manggilingan.

The storylines of wayang (puppet) relies on the "persona", which are different from the Western theater storylines that commonly present less expressive by emphasizing more on the logic of cause and effect based on the periodical system of the past, present, and future. The audiences of Western theaters are more interested in the underlying reasons that consciously span the plot. In contrast, the plots of wayang are arranged based on the "persona logics", in which the relationships refer to various strategies where an individual connects with others through actions. The audiences can enjoy the story plots that unite all kinds of characterizations, for example, the good that meets the evil, the rich that meets the poor, the noble that meets the savage, and the knight that meets the giant, and so on. Therefore, the setting of time is not the standard principle, as a storyline is built based on the logic of coincidence.

Both of the novels, including Kitab Omong Kosong written by Seno Gumira Ajidarma and Hubbu written by Mashuri, try to unearth the wayang (puppet) myth that originated from the narrative of Ramayana. This kind of literary attempt is different from the attempt committed by other Indonesian authors that commonly tend to be more interested in Mahabharata.

The story of Ramayana was created by Valmiki. It entered Indonesia through Gujarat from South India in the first centuries (BC) at the reign of Srivijaya. The Ramayana consists of 24,000 verses which are divided into seven kanda (volumes), namely Bala Kanda, Ayodhya Kanda, Aranya Kanda, Kiskend Kanda, Sundara Kanda, Yudha Kanda, and Uttara Kanda. Meanwhile, the story of Mahabharata consists of 100,000 couplets which are divided into 18 parwa (manuscripts).

\section{Deconstruction}

According to Derrida, deconstruction is not a theory or system of thought, however, rather a tactical effort to prove language instability as the basis for most of the available theories (Sim, 2002: 59). By developing Ferdinand de Sauserre's idea that emphasizes on the arbitrary relationship between the marker and the marked, Derrida stated that a number of ideas aimed to direct an individual to the nature of the arbitrary characteristics. As the Western cultural discourse (modernism) is established based on the belief in certainty, Derrida's idea will potentially stimulate or undermine a number of cultural assumptions that for long have been adhered in modernism.

In the concept of Derridian discourse, meaning always evolves in the process and has no standard and permanent interpretation, in which deconstruction is a full form of freedom in conducting an interpretation. Nurgiyantoro (2009) viewed that deconstruction could essentially provide a text reading strategy to subvert the notion by underlining the principle that a text has a number of components, such as basis, language system, and certain structures and meanings. More explicitly, deconstruction is a rejection against logocentrism. 
Deconstruction is perceived as a method of textual reading. It shows that every text always contains absolute assumptions and points out the fact that every assumption is always contextual: the assumption is always present as a historical social construction, thus it does not refer to the final meaning. The assumption is available as the historical traces. Derrida explained that people tended to separate texts from their contexts. One particular term, for instance, is removed from the context (from its trace) and perceived as a final meaning. Derrida called the treatment as logocentrism, which signifies the tendency to refer to certain metaphysics and the presence of certain absolute objects.

Umar Junus viewed deconstruction as a new perspective in literary research. Deconstruction actually offers an impetus to find everything that has yet received attention. It allows an individual to carry out an intellectual exploration with any means, without being bound by any rules which are considered universally applicable. Deconstruction, in a clear overview, is a strategy to present contradictions that hide behind the concepts which for long have been adhered in general. Common people used to understand Derrida's idea about deconstruction as a form of aggressive, radical, and destructive interpretation which replaces, destroys, dismantles, and questions the prevailing beliefs and potentially will lead to skeptical thinking. In fact, deconstruction is a combination of destructive and constructive nature.

The main aspiration for deconstruction is to uncover the meanings which for long have been marginalized, ignored, and hidden. When an interpretation is obliged to follow the standard rules under the control of authorities, deconstruction will arrive to harass and sue the authorities, as it functions to hinder the current beliefs which are adhered and upheld by the tradition and history.

\section{Methodology}

This study deployed a qualitative approach, as the approach provides an opportunity for the researchers to rely on their interpretation (Charmaz, 2011; Denzin \& Lincoln, 2011; Strauss \& Corbin, 2015; Sutopo, 2002). It adopted a descriptive-interpretative data analysis technique through a deconstruction method which prioritizes signature characteristics of critical thinking in establishing a new construction by destructing the old construction (Rohman, 2014: 71). The characteristics include: (a) the major philosophical concept of a text through the assumption that each text has meaning due to the message that the author wants to convey to the readers; (b) the peculiarities of philosophical expressions in terms of phrases and sentence structure; (c) the compilation of binary oppositions, as the reflection of thematic constructions of the major theme that will be further questioned; and (d) the new constructive effort, as a result of the destructuration of previous constructions. Deconstruction emphasizes the development of new construction by destroying the old construction.

The data consisted of the words, phrases, and sentences that contain the myth confirmation and myth deconstruction. Meanwhile, the data validity test utilized the triangulation technique (Stake, 2010: 123-125).

\section{Result and Discussion}

Through Kitab Omong Kosong which consists of three major chapters in various episodes, the author attempted to reaffirm the myth of Ramayana, and simultaneously rebel and dismantle the myth and values contained in the narrative which for long have been adhered by the society. 
The dismantlement was implicitly present at the initial part of the story. In Chapter I: "Persembahan Kuda" (Sacrificial Horse), the author did not highlight the old myth of Ramayana in his narration by introducing the Bala Kanda, however, he began it with the Uttara Kanda which is a less renowned final part of the Ramayana in Java. The section told about the return of Rama and Sita to Ayodhya after defeating Ravana. It narrated that the Ayodhya people doubted Sita's sanctity. Sita was then driven out of the kingdom and wandered until she gave birth to twins, Kusha and Lava before she was finally engulfed by the earth. This section is only found in the Ramayana story in Sanskrit version, instead of the old Javanese version. The exposure of the section implied that Ajidarma tended to refer to the Sanskrit version of Ramayana as the reference in writing his Kitab Omong Kosong.

The beginning of the novel apparently showed the rebellion to the myth (myth of freedom), especially to the figure of Rama whom in both Sanskrit and Old Javanese version of the Ramayana was posted as a hero that carried the truth, upheld justice, and avoided all bad deeds. The novel, on the contrary, described him as a king that could appear as a cruel figure as cited in the following excerpt:

"In a short time, the name of Sri Rama who was previously so fragrant as the conqueror of Lanka has shifted as an extremely frightening name. From Magada, the troops of Ayodhya continued to sweep the countries of Angga, Campa, Mantura, and Bangga by the shores. The enchanting city of Malini then turned into an ocean of fire. People were pushed to the sea. There was happening a vicious massacre. People who had surrendered and risen their hands with their half bodies drowning in the sea were still murdered mercilessly, making the sea full of lying corpses" (Ajidarma, 2013: 16).

In Kitab Omong Kosong, the figure of Rama whom in the narrative of Ramayana was posted as the incarnation of Lord Vishnu that became the world savior was portrayed as an ambitious king that sought for power by performing the horse sacrificial ritual. He released a horse that previously had been spelled by sorcery. Every region that the horse traversed should be defeated or conquered. The rebellion to the myth of Rama as the world savior existed in the following excerpt:

To every nation throughout the subcontinent, a declaration is announced: Ayodhya is carrying out a horse sacrificial ritual. There is no other way crueler than this to destroy and plunder other weaker nations, as every inch of the land in their countries that the horse traverses must surrender, submit, and concede to Ayodhya. Otherwise, a million troops of Ayodhya will destroy them... There is no country stronger than the country ruled by Rama, the knight and the conqueror of the giant Ravana that for centuries has stayed undefeated. How does it come to fight Rama? How is it even possible just to counterbalance him? (Ajidarma, 2013: 14).

“... The death of millions of people never dampened Lakshmana's zeal to rule over the territories that the white horse traversed... Now, the Commander was not waiting for the white flag to surrender. At night when all the people laid down asleep, the troops of Ayodhya kept on going, ravaging the villages and towns that they passed on their journey. Mahishmali, Mahishmati, Bojakata, Dasarna, and the entire Windya region were looted. The earth was scorched on every trail of their journey, smoke billowed into the sky, red flames burned. The horses kept running, carrying the assassins on their backs" (Ajidarma, 2013: 19).

In the Javanese narrative related to wayang, the war between Rama and Ravana indeed symbolized the battle between the evil and the truth, in which Rama was portrayed as the truth. 
However, Kitab Omong Kosong blurred the original plot. Even though Ajidarma still presented the war of Ramayana as the battle between the truth and the evil, he remained unclear in the representation of the truth and the evil themselves. Kitab Omong Kosong did not promote the story of the battle between Rama and Ravana, however, rather the battle between Rama and himself who was depicted of having the indications of Ravana's characters (Ajidarma, 2013: 35).

The portrayal of the truth and the evil was blurred and remained undichotomized through a clear and extreme way, as indeed resented in the old narrative of wayang (puppet). The novel signified the author's complicated attempt in presenting the problems and dispute between Rama and Ravana. Ajidarma wanted to provoke his readers by highlighting the idea that every human being had the potential to be good and evil at the same time. In the wayang (puppet) story, the good is always "whitened", while the evil is always "blackened" through the belief that the white will never unite with the black, the good shall always be separated from the evil, and the good shall always win and the evil shall always loose. Implicitly, Kitab Omong Kosong stated that the white and the black could unite in life, as humans might never want to succumb to the evil, however, they could not be insisted to bear the good itself. Sometimes, the evil could be so powerful, while the good could suffer, and vice versa.

Even though the novel was inspired by the narrative of Ramayana, Ajidarma still presented his concern to the poor people and those in needs. His concern existed through the emergence of several main characters that were never mentioned in the original story of Ramayana. Satya and Maneka were the two new characters that emerged and dominated the story more than the standard figures, such as Rama, Lakshmana, Vibhisana, and others. Surprisingly, Satya and Maneka came from the marginal group or kawula alit (common people). Therefore, Kitab Omong Kosong clearly appeared as a caragan (the presentation of a new narrative that neglects its original rules and background) of Ramayana which was increasingly laden with various interpretations and processing of various sources or versions which were considered as the depiction of truth.

Satya and Maneka appeared as the main characters. Satya was an innocent rural lad who lost his hometown and relatives due to the horse sacrificial ritual committed by Sri Rama. In another side, Maneka was a slut who was born in a brothel and tried to run away from her unfortunate fate. The emergence of Satya and Maneka who came from the commoners were presented as the heroes and trusted by Hanuman to find and spread the teachings of a special book that could save the world civilization. The existence of both figures reflected Ajidarma's attempt to dismantle and rebel against the myth of wayang in Java.

The myth of Javanese puppetry is perceived as a culture of satriya (knight). It introduces the ideal concept of human as a satriya pinandhita (a knight who possesses soul as a priest). Through the culture, the concept of satriya (knight) always appears through a mesmerizing and subtle portrayal as the brave and flawless figure that the kawula alit (common people) should refer to. Through the emergence of Satya and Maneka as the protagonists that succeeded to save the world, despite their origins from the common society, the myth of satriya (knight) eventually collapsed. The satriya (knights) were no more noble than ordinary people. Rama, Lakshmana, Vibhisana, and Sugriva were no more noble, superior, and dignified than Satya who was the son of a farmer and Maneka who was a slut.

The novel also overturned the myth of power and the concept of leadership in Javanese society. Since the Hinduism culture was disseminated in Indonesia through the puppetry, the concept of power in Javanese society referred to the king or satriya (knight). The king was absolutely depicted as the warenaning Allah (incarnation of God). In puppetry term, a satriya 
(knight) is described as "gung binathara bau dhenda anyakrawati, wenang wisesa ing sanagari, ber budi bawa leksana" (the king that rules through a manner as the God rules, the keeper of the law, the ruler of the world, the highest authority of the whole states, and the figure that possesses noble characters and brings justice to all human beings). Therefore, the common people had no other choices, instead of ndherek karsa dalem (surrendering to the command of the king).

This concept was completely demolished in Kitab Omong Kosong. The novel reconstructed the narrative of Ramayana differently, as the common people such as Satya and Maneka appeared as the personifications of people that no longer relied on the king and possessed more power than the satriya (knights). Due to their persistence, Maneka and Satya even could be more dignified than Rama.

The concept of the puppeteer in Javanese puppetry was also dismantled. The role of puppeteer and playwriter (Valmiki, as the writer of Ramayana) for long were portrayed as the representative of God on the Earth and ruled over the life of their puppets. However, the novel presented them as the figures who were confused when they met with the fictional characters that they created. They even could not end the story plot of those characters. As a result, many puppet characters protested and finally came out of Valmiki's storyline (Ajidarma, 2013: 437-531).

Ajidarma's concern to the marginalized people that were neglected from the important parts of the story even dominated the novel. He defended them implicitly in some parts of the novel, as he picked up the old stories that frequently highlighted the fate of the marginalized people, for instance, the story of Siawatrikalpa Kakawin (Ajidarma, 2013: 159-170). The story was composed by Mpu Tanakung that specifically mentioned marginal groups, namely the people who survived through hunting and food gathering and were considered as a primitive society. The story portrayed the figure of Lubdhaka as a despicable hunter who could enter the Heaven, as in the time of his despair, hunger, and fear, he accidentally made Siwaratrikalpa sacrifice that people had forgotten. The narrative ought to be placed within its context. It was addressed to the marginal people who were expected to submit to the royal order and social regulation, however, they could achieve existence through their opposition.

The presentation of the common people, instead of the satriya (knight) as the new figures in the new myth narrated in the novel was even stronger, as the author called the figure of Togog at the end of the story. In contrast to Semar, Togog was indeed an outcast servant that had hardly been discussed through the depiction of a substantial role. In this novel, Togog held the role as the writer of Kitab Omong Kosong which was sought by the satriya (knights) and commoners (represented by Maneka and Satya) to save the world civilization (Ajidarma, 2013: 619).

Meanwhile, Mashuri through his Hubbu (2007) picked up the initial part of Ramayana story for his narration, namely the plot before the birth of Ravana. Hubbu highlighted the life story of several figures, including Visrava, Danaraj, and Sukesh in the Lokapala Kingdom as an interesting tragedy that inspired him to write the story. The figures of the tragic story appeared through the main figure named Jarot or Abdullah Sattar. Through the figures (especially Jarot), Hubbu depicted syncretism as a "cultural journey" to the new "homeland" that sometimes saved the obstacles and challenges. Syncretism in Hubbu emerged not only as the teachings but also aesthetic rules. The novel presented a syncretism of the santri (Islamic boarding school students) and abangan (syncretic Javanese Muslims) culture through oral-literary heritages within the boundary of the narrative convention of wayang (puppet) and babad (historical manuscript).

Hubbu introduced how Javanese culture grew and developed from syncretism. The novel portrayed an extreme way of how two different worlds, including the world of santri and the 
world of abangan were brought together and merged into a central figure named Jarot or Abdullah Sattar. Sattar or Jarot was born from the pesantren cosmology or the world of santri which was loaded with various impulsive teachings in pesantren (Islamic boarding school). He ought to fully associate and plunge into the treasury of the santri without any compromise. It implied the mythology and cosmology of santri which were bold with Islamic teachings and Arabic culture.

As a santri, Jarot was familiar with the system of pesantren, as transparently described in the following excerpt:

Memorization became a lump of the burden that anyone in Arabic schools could not push aside... It's not only about Amtsilatus Tashriffiyah which contains the examples of changes in Arabic words as echoed by Jarot. They called it Sharaf. Although there would be other lines of Sharaf, such as Nadlan Maqshud that he would face after accomplishing his level, other lessons would also subject to memorization, including the pair of Sharaf, such as Nahwu Wadlih, Matan Jurumiyah, Imrithi, and even the combination of the two Arabic Sciences: Alfiyah Ibn Malik. Perhaps, Muthamimmah would be the only thing that required no memorization (Mashuri, 2007: 22).

"Qalla muhammadun huwabnu maliki, ahmadu rabbillaha khaira maliki", Jarot reminded himself that he once comprehended the line to the core of his heart, as well as the next lines written in Alfiyah. He was a teenager at that time... He spent his evening with the memorization of tajwid, aqidah, akhlaq, and other lessons, from sir in the Javanese language to nadlaman in the Arabic version (Mashuri, 2007: 22).

The cosmology world of pesantren that surrounded Jarot had received the influence from another cosmology world, namely the abangan. The introduction of the early cultural combination in the novel was presented as Jarot watched a puppet show. For Islamic boarding school environment, the puppet was a forbidden form of art, however, Jarot dared himself to watch the show even though it resulted in punishment from one of his Ustadz (Islamic school teacher). The encounter between Jarot and the Javanese culture (wayang) was quoted in the following parts:

"Who watched the puppet show last night?"...

I raised my hand since I did watch the show. Surprisingly, Somad, Juned, and Sadzali also raised their hands. Sanusi, Mr. Ali's son did too.

"All that watched the puppet show must go out and put off their clothes!," Mr. Ali said. No words came out of our mouths, neither refutation nor whatever it was. Moreover, Mr. Ali firmly said that the puppet is haram! Due to a series of illicit acts, we had broken the rules and we had to be punished. Approximately, that was the assumption (Mashuri, 2007: 3233).

"Yes, I watched the puppet show last night. The puppet show that for the first time I followed until the morning came... Somehow, I was carried away. Even when the old people who used to watch the show had felt drowsy, I was still wide awake. Up all night, I was stunned" (Mashuri, 2007: 33).

The encounter with Javanese culture also occurred when Jarot gained a new "knowledge" from his mate, Jabir. The knowledge was totally different from those that he received in the pesantren. It was a Javanese witchcraft, as quoted in the following excerpt: 
I asked him to write down the spell that he offered in my lesson book: "Ingsun amatak ajiku si jaran goyang, teteger tengahing pasar, gegamane cemethi, sada lanang saka swarga, sun sabetake gunung gugur, segara asat, bumi bengkah, sun sabetake langit butul kang langit sap pitu, sun sabetake atine si jabang bayi ..... teka welas teka asihandeleng badan sliraku, manut muturut sakkarepku". Once I read the spell, I immediately could memorize it. I pronounce it without looking at the text. (Mashuri, 2007: 40)

The encounter of both santri and abangan culture that Jarot experienced grew stronger, as he met with Wak Tomo, an adherent of Javanese ritual tradition that worked as a seller in Alas Abang market. By meeting with Wak Tomo, Jarot expanded his knowledge about Javanese ritual tradition or mysticism, as quoted in the following excerpt:

"It was Wak Tomo who taught me about Javanese culture from a different point of view, which was more than heresy, or something which indeed was not heresy, however, mentioned that way by the rural people. I was also taught about patigeni, ngebleng, mutih, ngalong, as well as silat based on the Javanese traditional rituals... Ah, a desire that suddenly stretched. I felt my body and soul strangely burned and trembling. Slowly creeping, warm, and igniting my guts that for long had remained silent" (Mashuri, 2007: 41).

In the concept of abangan culture, the knowledge about Sastra Jendra (myth) is the culmination of the synthesis between the santri and abangan culture. The myth of Sastra Jendra Hayuningrat in Hubbu continued to haunt Jarot, as he attempted to find out its meaning throughout his life. Even, the obsession of the knowledge also caught the attention of his daughter, Aida who tried to track it down to her father's homeland.

In its later development, the term Sastra Jendra in Javanese mysticism was interpreted as a secret concept or teachings about Manunggaling Kawula-Gusti which in Islamic Sufi concept refers to Al-Hulul, Al-Ittihad that continued to manifest in the concept of Wihdatul Wujud. In the teachings of Sastra Jendra and Wihdatul Wujud, the secret manifestation of God is revealed, as God resides in humans. Those who love and those who are loved have merged into one. As a myth or belief, Sastra Jendra has led the Javanese society to comprehend the concept, as a means to achieve perfection and happiness. In the context of Javanese philosophy (Javanese mysticism), "Sastra Jendra Hayuning Rat Pangruwating Diyu" is the concept of the highest knowledge that saves humans and fights against the giants extraordinarily. Therefore, the Ramayana story depicted that there were no characters who were able to reveal and retell the knowledge except Visrava who received the grace from Gods. Due to the magnificent contents of the teachings, the world would shake if he shared the Sastra Jendra. Sastra Jendra is a secret knowledge in the Javanese philosophy, as the manuscript was not available in the Indian version of Ramayana. It refers to the Kawi Literature (ancient Javanese literature) which is estimated to originate from 996 BC, namely in the Uttara Kanda.

The term Sastra Jendra firstly appeared in the story of Arjoena-Sasra Bahoe written by R. Ng. Sindoesastra (Balai Pustaka Weltevreden, 1930): Sastra Jendra Hayuningrat, pangruwat barang sakalir, kapungkur sagung rarasan, ing kawruh tan wonten malih, wus kawengku sastradi, pungkas-pungkasaning kawruh, ditya diyu raksasa, myang sato sining wanadri, lamun weruh artine kang Sastra Jendra. Rinuwat dening bathara, sampurna patinireki, atmane wor lan manusa, manusa kang wus linuwih, yen manusa udani, wor lan dewa panitipun, jawata kang minulya mangkana prabu Sumali, duk miyarsa tyasira andhandhang sastra. (The supreme knowledge of the salvation of the universe, to repent things, everyone used to talk about it, now that knowledge has gone, it has been framed by exalted literature, the conclusion of this knowledge is all kinds of 
giants, and all animals in the wilderness, if one understands the meaning of Sastra Jendra, he shall be treated by Gods, he shall find the perfect death, his soul will gather with humans, the glorified humans, the humans who understand (Sastra Jendra), his death will be with Gods, the glorified Gods, so as Prabu Sumali, when he heard the teachings, his heart desired of knowing the Sastra Jendra).

As a myth or belief, Sastra Jendra has led Javanese society to comprehend it as a means to achieve perfection and happiness. In Indonesia, there is a spiritual culture organization called Sastra Jendra Hayuningrat Pangaruwating Diyu association. The association is based in Jakarta and approved by KRMH. Darudriyo Soemodiningrat. The association believes in the existence of God which is incomparable with anything. According to the association, the vast teachings of Sastra Jendra came from the palace as the values adhered by the kings. Meanwhile, the knowledge managed by the association is limited to the teachings that only deal with the improvement of character and behavior. The notion perhaps becomes the reason for Mashuri to put the Sastra Jendra in his novel. Amid the conflict between the Islamic and Javanese culture experienced by Jarot as his daily problems in the chaotic civilization, this ultimate knowledge is expected to provide solutions that can reconcile and solve the problems.

Hubbu denoted the teachings of Javanese tradition in terms of "Javanism as a syncretical and total thought". The novel, as a modern literary product also presented a traditional/local narrative convention of syncretism (oral genre, wayang genre, and babad genre) together with the modern narrative convention.

The syncretism of the traditional narrative convention in Hubbu appeared, as the moral teachings were brought up through the episodic frameworks. The traditional narrative convention of babad (chronicle) genre appeared through the prominence of trah (breed) and the delivery of mystical elements. Jarot or Abdullah Sattar in Hubbu often questioned the awareness of trah, as the successor of the pesantren that reinterpreted the importance of the "genealogical tree" of his family (Mashuri, 2007: 173). The traditional narrative convention in wayang (puppet) was also very visible through the naming of the wayang characters through the appearance of Danaraj and Visrava that manifested in Jarot. In contrast, the modern novel genre was traceable through contemporary life and individualistic attitude shown by the characters of the story.

The characteristics of a syncretic structure in Hubbu also appeared in the absence of subelemental domination. The narrator sometimes existed everywhere and nowhere, as the story deployed the "I'm narrative" technique. The plot was not arranged in a linear-climax flow from the small to larger conflicts, however, established in episodes that reflected the characteristics of cakra mendangingan (cyclical thinking), thus the plot order was more concerned with the textual principles rather than structural principles.

\section{Conclusion}

The study concluded that Kitab Omong Kosong written by Seno Gumira Ajidarma attempted to utilize the old mythology and cosmology to knit another new mythology based on the current socio-cultural problems. Through the attempt, the author unraveled a number of old myths (myth of freedom) and confirmed other myths (myth of concern). The myth dismantlement covered a number of aspects, including the figure of Rama, the culture of satriya (knight), and the concept of power and leadership in Javanese society. Meanwhile, the myth confirmation was found in Eastern philosophical concepts, including the concept of silence or meditation, as a 
representation of another effort besides rationality in achieving a more comfortable and just world.

The novel also appears as a small treasury or mini encyclopaedia about the classic Eastern and Old Javanese narratives, as it contains not only passages in the Ramayana (including Rama Tambak, Anoman Duta, and Sinta Obong) but also other passages that have no relation to Ramayana, such as Jataka Mala, Siwaratri Kalpa, and Bubukhshah-Gagang Aking. By reading Kitab Omong Kosong, readers are invited to explore the old serat (manuscript) and kakawin (poems) and contemplate the values of wisdom without ignoring their critical thinking.

In contrast, besides processing the myth of Ramayana, Hubbu which was written by Mahuri also processed the abangan (syncretic Javanese muslim) culture, such as the Sastra Jendra by emphasizing on the aspects of syncretism. The novel mainly showed the syncretism of old narrative elements, such as the oral-literary genre, wayang (puppet) genre, and babad (chronicle) genre; in addition to the processing of a modern narrative.

\section{References}

Abdullah, Taufik. (1991) “Siti Nurbaya: Roman, Wanita dan Sejarah. Kalam. Mei.

Ajidarma, Seno Gumira. (1994). Kitab Omong Kosong. Yogyakarta: Bentang.

Allen, Pamela. (2004). Membaca, dan membaca lagi. Re interpretasi Fiksi Indonesia. Magelang: Tera.

Amir, Hazim. (1991). Nilai-nilai Etis dalam Wayang.Jakarta: Pustaka Sinar Harapan.

Aminudin. (1987). Pengantar Apresiasi Karya sastra. Bandung: Sinar Baru.

Junus, Umar. (1981). Mitos dan Komunikasi.Jakarta: Sinar Harapan.

Harjowirogo, Marbangun. (1989). Manusia Jawa. Jakarta: Masagung.

Hadiwidjana. (1954). Sarwasastra Djawa Kuna. Yogyakarta: U.P Indonesia.

Hastjarja, Pudja Edi. (1984) “Variasi Sistem Nilai Budaya Jawa”. Dalam Basis.XXXIII Januari, Vol VI: $43-49$.

Indrajati, Sang. (1977). Kitab Weda Mantri. Solo: Sadu Budi.

Ismunandar. R.M. (1988). wayang, Asal-usul dan Jenisnya. Semarang: dahara Prize.

Kamajaya. (1985). Serat centhini (Suluk TambangRaras). Yogyakarta: 1985.

Lombard, Denys.(2005). Nusa Jawa: Silang Budaya, Jilid I. Jakarta: Gramedia.

Denys Lombard, (2005). Nusa Jawa: Silang Budaya, Jilid II. Jakarta: Gramedia.

Denys Lombard, (2005). Nusa Jawa: Silang Budaya, Jilid III.Jakrta: Gramedia.

Mahayana, Maman S. (2005). 9 Jawaban Sastra Indonesia. Jakarta: Bening Published.

Mashuri. 2007. Hubbu. Jakarta: Gramedia Pustaka.

Mustika, Ari, Aldrin \& Luluk N. (2012). Stories of Wayang di Batas Angin by Yanusa Nugroho: Indonesian Wayang in Modern Literature. International of Economics Devolepment E Research, Vol $51 . P 17$. 
Nurgiyantoro, B \& Anwar E (2017). Re-actualisation of Puppet Charactes in Modern Indonesia Fiction of the 21 century. 3L: The Southest Asian journal

Ramli, Wan Nor Raihan \& Farah aini Lugiman. (2012). The Contribution of Shadow Puppet's Show through Engaging Social Communication in Modern Society. Procedia Social and Behavioral Sciences.35 (2012) 353-360.

Saryono, Djoko. (1995) “Transformasi Nilai-Nilai Budaya Jawa dalam Novel Indonesia. Jurnal Bahasa dan sastra Indonesia.Th.1, No.2: 17-26 Agustus 1995.

Sindhunata. (1984). Anak Bajang menggiring Angin. Jakarta: Gramedia.

Wijaya, Putu. (2002). Perang. Jakarta: Grafiti.

Wardoyo, Subagio Sastro. (1989). Pengarang Indonesia Sebagai Manusia Perbatasan. Jakarta: Balai Pustaka.

Zoetmulder, P.J.(1991) “Triwarga dalam Kesusastraan Jawa Kuno”. Basis, XL, No.9. September 1991: 25-32. 